\title{
Development of a Functional Food Product Using Guavas
}

\author{
Priyanka Patel, Kayla Ellis, Rajitha Sunkara, Loius Shackelford, Simon Ogutu, \\ Lloyd T. Walker, Josh Herring*, Martha Verghese \\ Nutritional Biochemistry and Product Development Laboratories, Department of Food and Animal Sciences, \\ Alabama A\&M University, Normal, AL, USA \\ Email: ${ }^{*}$ josh.herring@aamu.edu,martha.verghese@aamu.edu
}

Received 22 June 2016; accepted 28 August 2016; published 31 August 2016

Copyright (C) 2016 by authors and Scientific Research Publishing Inc.

This work is licensed under the Creative Commons Attribution International License (CC BY). http://creativecommons.org/licenses/by/4.0/

c) (†) Open Access

\begin{abstract}
The global market of functional foods and demand for a healthy lifestyle among consumers in recent years is growing. Guava is a highly perishable fruit and a rich source of vitamin C. Guava Cheese (GC) is a semi-solid concentrated fruit product that could be consumed as a snack. The objectives were to develop a guava cheese (GC) and determine the antioxidant potential of the product. Formulation consisted of guava puree with added sucrose or agave, chia seeds and almonds. Pectin was added at select concentrations $(0.5 \%, 1 \%, 1.5 \%)$ along with citric acid to enhance the consistency of GC. Physiochemical and sensory parameters were analyzed for extended shelf life (3 months) studies. Moisture content, $\mathrm{pH}$, water activity, color $\left(\mathrm{L}^{*}, \mathrm{a}^{*}, \mathrm{~b}^{*}\right)$ and texture profile analysis (hardness, springiness, cohesiveness, gumminess, chewiness) did not change over the 90-day period. Ash, protein and fat contents of $0 \%$ pectin were $2 \%$ lower than GC with pectin. Sensory parameters (firmness, mouthfeel, flavor and overall acceptability) of GC $0 \%$ pectin and 1\% GC were similar. Total content in $0 \%, 0.5 \%, 1 \%$, and $1.5 \%$ pectin added GC were $150.49 \pm 32.76$, $340.17 \pm 54.65,346.39 \pm 53.04$, and $355.72 \pm 14.24 \mathrm{mg}$ gallic acid equivalent (GAE)/100g. Flavonoid content in $0 \%, 0.5 \%, 1 \%$, and $1.5 \%$ GC were $159.73 \pm 13.31,332.77 \pm 13.31,341.65 \pm 15.37$, and $350.52 \pm 16.60 \mathrm{mg}$ catechin equivalent (CE)/100g. Similarly, antioxidant of potential measure by DPPH radical scavenging was similar in all samples $\left(\mathrm{IC}_{50}\right.$ at $\left.0.8 \mathrm{mg} / \mathrm{ml}\right)$. Guava cheese may be utilized as a healthy fruit snack because of added alternative sweeteners and functional ingredients to obtain health benefits. Adding pectin to guava cheese improved functionality by increasing antioxidant potential as well as physical properties.
\end{abstract}

\section{Keywords}

Guava, Guava Cheese, Functional Food, Antioxidants, TPA

\footnotetext{
${ }^{*}$ Corresponding author.
}

How to cite this paper: Patel, P., Ellis, K., Sunkara, R., Shackelford, L., Ogutu, S., Walker, L.T., Herring, J. and Verghese, M. (2016) Development of a Functional Food Product Using Guavas. Food and Nutrition Sciences, 7, 927-937. 


\section{Introduction}

Consumption of five fruit servings per day has been recommended for a healthy life style and to reduce risk of chronic diseases [1]. Consumers are aware of healthy diet and they believe that an increase in consumption of fruits will help them to improve their longitivity and reduce metabolic disorders [2] [3]. Fruits have been recognized as a good source of many nutrients. Individuals who consume fruits as part of their daily diet have a reduced risk of chronic diseases. According to the World Health Organization and the Food and Agriculture Organization at least $400 \mathrm{~g}$ of fruit and vegetables per day is recommended. Incorporating citrus fruits and berries that contain phytochemicals, may improve good health and reduce the risk of diseases [4]-[6]. Restructured fruit products may be a convenient value added substitute for natural fruits with similar health benefits. Fruit leathers or fruit snacks provide lower caloric values than other food snacks that are available in the market [7]. Fruits such as guava, orange, papaya, pineapple and strawberries have a tangy flavor due to the high content of ascorbic acid, which favors the development of the snack product. Psidium guajava Linn. was first named by Linnaeus in 1753 [8] and was called guayabo by the Spanish chronicler Oviedo [9]. Guava is a seasonal tropical fruit and is highly perishable, which is widely consumed as a fresh or processed food product. Guava tree and its components have potential therapeutic effects and are being used as folk medicine in many parts of world [10]. Guava fruit is four to ten times richer in vitamin C than citrus fruits and also contains dietary fiber. Firm fresh guava contains about 56 - 500 mg of ascorbic acid, but the skin contains the highest amount of ascorbic acid [11] [12]. Guava also has a pleasant aroma and is a good source of vitamin A and pectin. Guava contains about 84\% moisture, and has a lower content of carbohydrates, protein and fat [13]. Unlike strawberry, oranges or bananas, utilization of guava in the food processing industry is very low. About 1.6 million tons of guava are produced per year but the utility is very low due to the post-harvest losses and causes disposal problems [9] [14].

A variety of guava products are available in the market such as jellies, juices, ice creams, yogurt, and nectars [13]. Guava can be eaten raw, but can also be consumed as a sweet meal such as guava cheese or paste [15]. Application of guava leaves in culinary is well developed in many countries. Restructured fruit snacks can be modified with addition of natural fructans to develop value added products. Agave fructose syrup has received attention as an alternative to traditional sweeteners, such as sucrose and honey [16]. Agave has many advantages in the food industry because of its health benefits such as natural prebiotics, and dietary fiber. It also acts as stabilizer, sweetener, and moisturizer in food products. Raspberries belong to the genus Rubus and are sources of many bioactive compounds such as vitamin C, phenolic compounds, and anthocyan in which associated with a reduced risk of chronic diseases [17]. Researchers have found that consumption of dried fruits and nuts lowers risk of metabolic disorders. Almonds are widely acceptable by consumers and are a good source of protein, fiber, potassium, monounsaturated fatty acids (MUFA) and polyunsaturated fatty acids (PUFA) [18]-[20]. Nowadays, chia seeds have gained tremendous importance in the food industry due its potential health benefits. Chia seeds are a natural source of omega-3 fatty acids, dietary fiber, protein, bioactive compounds, and are gluten-free and contain no toxic components [21]. Thus, the proposed study is aimed for value addition of guava cheese with different concentration of pectin $(0.5 \%, 1 \%, 1.5 \%)$, chia seeds, almonds and agave and to investigate the physiochemical and sensory parameters of guava cheese.

\section{Material \& Methods}

\subsection{Preparation of Guava Cheese (GC)}

Fresh guava and fresh raspberries were obtained from a local grocery store in Huntsville, Alabama. Guava fruits were washed thoroughly with tap water and diced in fourth. Diced guava fruits were steamed at $250^{\circ} \mathrm{F}$ for 30 min. Softened guava fruits and fresh raspberries were pureed in blender and sieved to get a homogenous pulp without seeds in 3:1 ratio. Pectin was used in different ratio of $0 \%, 0.5 \%, 1 \%$ and $1.5 \%$ to acquire the same consistency as control (0\%). For preparing guava cheese, $1000 \mathrm{~g}$ of pulp (guava and raspberries) was cooked to one third of its original volume and added $25 \mathrm{~g}$ of sugar for control (0\%), $25 \mathrm{~g}$ of agave for the rest of the treatments, $0.5 \mathrm{~g}$ of citric acid, $1.5 \mathrm{~g}$ of butter and $2 \mathrm{~g}$ of chia seeds and almonds were added. Pulp was cooked until it became like dough consistency and spread on a greased pan. Samples were stored at refrigerated temperature for determination of three months shelf life. Physiochemical analysis was performed on fresh guava cheese. 


\subsection{Characterization of Guava Cheese (GC)}

\subsubsection{Proximate Composition}

Guava cheese (GC) was assessed for proximate analysis i.e. moisture, ash content, crude protein, crude fat, carbohydrate and total sugars according to their respective AOAC methods [22]. The color of GC was determined using a bench top spectrophotometer (Colorflex Model 45/0, Hunterlab Inc., Reston) based on the Hunter L, a, b color scale [23]. pH of GC was measured using a Fisher Scientific ${ }^{\mathrm{TM}}$ accumet $^{\mathrm{TM}}$ Excel XL15 pH/mV/Temperature Meter lab (13-620-130) according to the AOAC official method 943.02. Water activity of GC was measured using the RototronicHygrolab water activity (Aw) meter (Hygrolab C1, Hauppauge, NY).

\subsubsection{Texture Profile Analysis}

Texture parameters (hardness, springiness, cohesiveness, gumminess and chewiness) of guava cheese samples were measured using a texture analyzer (TexturePro CT3 V1.2 Build 9, Brookfield Engineering Labs, Inc.). The probe was calibrated before the test was conducted. A sample was placed centrally beneath the probe [(TA3/100 $25.4 \mathrm{~mm}$ diameter cylinder clear acrylic probe $(35 \mathrm{~mm}$ long; radius $0.35-0.43 \mathrm{~mm}$ )] in order to meet with a consistent flat surface. The compression test was selected using a $50 \mathrm{~kg}$ load cell and sample was compressed to $75 \%$ of its original height. The strain required for $75 \%$ compression was recorded using the following conditions: pretest speed: $2.0 \mathrm{~mm} / \mathrm{s}$, test speed: $0.5 \mathrm{~mm} / \mathrm{s}$, post-test speed: $0.5 \mathrm{~m} / \mathrm{s}$, compression distance: $25 \%$ and trigger type: distance, and trigger load: auto $7 \mathrm{~g}$. The values reported were the average of three readings.

\subsubsection{Sensory Analysis}

Sensory evaluation was conducted based on a 5-point hedonic scale with untrained panelists ranging in age from 16 - 40. Panelists evaluated the handfeel, mouthfeel, flavor, and overall acceptability of guava cheese; $5=$ extremely like, 4 = moderately like, 3 = neither like nor dislike, 2 = moderately dislike and 1 = extremely dislike.

\subsubsection{Sample Extraction}

For determination of antioxidant potential of guava cheese, methanol extracts (ME) of GC were prepared following the method developed by [24] with slight modifications. A known quantity of guava cheese powder was soaked in $80 \%$ methanol for 24 hours with continuous shaking. The extracts were centrifuged at 10,000 $\times \mathrm{g}$ for $15 \mathrm{~min}$. Supernatants were filtered using a Whatman filter paper and the filtrates were evaporated to dryness at $40^{\circ} \mathrm{C}$ using a rotary evaporator (Buchi Rotavapor R-215, USA). Extracted samples were further filtered using solid phase extraction (SPE) method (Bond Elut C18). Eluate was evaporated to dryness at $40^{\circ} \mathrm{C}$ and stored at $-20^{\circ} \mathrm{C}$ for determination of physiochemical properties of GC.

\subsubsection{Total Phenolic Content (TPC)}

Total polyphenols were determined following the Folin-Ciocalteu's method using gallic acid as standard [25]. Folin-Ciocalteu's reagent $(12.5 \mu \mathrm{l})$ along with $7 \%$ sodium carbonate $(125 \mu \mathrm{l})$ was added to the guava extracts. Samples were then incubated for $90 \mathrm{~min}$ at room temperature. The absorbance was measured at $750 \mathrm{~nm}$ using microplate reader (Synergy HT, Bio Tek Instruments, Winooski, VT, USA).

\subsubsection{Total Flavonoid Content}

Flavonoid content was determined using an aluminum chloride colorimetric assay using catechin as a standard [26]. Samples, $7.5 \%$ sodium nitrite $(7.5 \mu \mathrm{L})$ and $15 \mu \mathrm{L}$ of $10 \%$ aluminum chloride were added to $1 \mathrm{M} \mathrm{NaOH}$. Absorbance was measured at $520 \mathrm{~nm}$ after 5 min incubation. Total flavonoid content was expressed as $\mathrm{mg}$ of catechin equivalent (CE) per $100 \mathrm{~g}$.

\subsubsection{Antioxidant Activity of Guava Cheese}

DPPH (2,2-diphenyl-1-picrylhydrazyl) radical scavenging activity was determined using [27] method. DPPH $(0.1 \mathrm{M})$ solution was briefly added to $40 \mu \mathrm{l}$ of samples. The absorbance was read at $517 \mathrm{~nm}$ for $90 \mathrm{~min}$ at $30 \mathrm{~min}$ interval in dark room temperature. Percentage of DPPH inhibition was calculated as follows:

$$
\% \mathrm{DPPH}=\left(\mathrm{A}_{\text {Control }}-\mathrm{A}_{\text {Sample }} / \mathrm{A}_{\text {Control }}\right) \times 100
$$

\subsubsection{Statistical Analysis}

All the data obtained from chemical analysis were analyzed using the SAS 9.2 version. Means were separated 
using Tukey’s standardized range test and ANOVA was used to determine significant differences among treatment groups. Level of significance was set at $\mathrm{p} \leq 0.05$.

\section{Results}

\subsection{Proximate Composition}

Guava cheese (GC) $(0 \%, 0.5 \%(\mathrm{P}), 1 \%(\mathrm{P}), 1.5 \%(\mathrm{P}))$ was analyzed for moisture, ash content, crude protein, crude fat, carbohydrate and total sugars using standard AOAC methods on day 0 and results are shown in Table 1. Ash content $(0.77 \%-1.01 \%)$ and protein content $(2.38 \%-3.53 \%)$ in GC was significantly $(\mathrm{p} \leq 0.05)$ higher in $0.5 \%(\mathrm{P}), 1 \%(\mathrm{P})$ and $1.5 \%(\mathrm{P})$ compared to the $0 \%(\mathrm{P})$. However, ash content and protein content among pectin added treatments did not differ $(\mathrm{p} \leq 0.05)$. Moisture, crude fat, carbohydrate and total sugar content of $0.5 \%$ $(\mathrm{P}), 1 \%(\mathrm{P})$, and $1.5 \%(\mathrm{P})$ were not significant $(\mathrm{p} \leq 0.05)$ among all types of GC.

\subsection{Color, $\mathrm{pH}$, and Water Activity}

$L^{*}$, $a^{*}$, and $b^{*}$ scale of guava cheese (GC) was measured for the 90-day storage period at 30-day intervals (Figure 1). Attributes of color for $0 \%(\mathrm{P}), 0.5 \%(\mathrm{P}), 1 \%(\mathrm{P})$ and $1.5 \%(\mathrm{P})$ were consistent throughout the observation period ranging from 33.41 to $36.62\left(\mathrm{~L}^{*}\right), 12$ - $14\left(\mathrm{a}^{*}\right)$ and 19 - $22\left(\mathrm{~b}^{*}\right)$ (day 0 - 90). Increase in pectin concentrations $(0.5 \%, 1 \%, 1.5 \%)$ of did not affect lightness, redness and yellowness of GC. $\mathrm{pH}$ values of $0 \%(\mathrm{P})$, $0.5 \%(\mathrm{P}), 1 \%(\mathrm{P})$ and $1.5 \%(\mathrm{P})$ were consistent throughout the observation period ranging from 3.5 to 3.6 and 0.802 to 0.856 (day 0 - 90). $\mathrm{pH}$ and water activity of GC was similar with or without addition of pectin (Figure 2).

\subsection{Texture Profile Analysis}

Texture profile analysis (TPA) was determined during the 90-day storage period based on the primary (springiness, cohesiveness, hardness (N/g)) and secondary parameters (gumminess and chewiness) of GC with different concentrations of pectin (Figure 3). Increased concentration of pectin significantly $(p \leq 0.05)$ increased all texture parameters of GC. However, no significant $(\mathrm{p} \leq 0.05)$ difference was observed over 90-day storage. On day 0 , GC with $0.5 \%(\mathrm{P}), 1 \%(\mathrm{P})$ and $1.5 \%(\mathrm{P})$ was springiness $(1 \%, 7 \%$ and $12 \%)$, cohesiveness $(3 \%$, $8 \%$, and $17 \%)$, hardness $(13 \%, 22 \%$ and $25 \%)$, gumminess $(14 \%, 17 \%$, and $41 \%)$, and chewiness $(10 \%, 16 \%$ and $54 \%)$ higher compared to the $0 \%(\mathrm{P})$.

\subsection{Total Phenolic and Flavonoid Content of Guava Cheese (GC)}

Total phenolic and flavonoid content was investigated using solid phase extraction (SPE) method for control (0\%) and GC with different concentration of pectin and shown in Table 2. Total phenolic content of $1.5 \%(\mathrm{P}), 1 \%$ $(\mathrm{P})$, and $0.5 \%(\mathrm{P})$ GC was significantly $(\mathrm{p} \leq 0.05)$ higher compared to $0 \%(\mathrm{P})$. However there were no significant differences were observed among the treatments. Phenolic content of GC with $0.5 \%(\mathrm{P}), 1 \%(\mathrm{P})$, and $1.5 \%$ (P) was 9\%, 19\%, and 24\% higher compared to 0\% (P) GC. Similarly, flavonoid content showed a similar trend as total phenolic content of GC. Flavonoid content of GC with $0.5 \%(\mathrm{P}), 1 \%(\mathrm{P})$, and $1.5 \%(\mathrm{P}) 1 \%, 7 \%$, and $8 \%$ higher compared to the $0 \%(\mathrm{P}) \mathrm{GC}$.

\subsection{Antioxidant Activity of Guava Cheese (GC)}

DPPH (2, 2-diphenyl-1-picrylhydrazyl) radical scavenging activity of GC (0\% (P), 0.5\% (P), 1\% (P), 1.5\% (P))

Table 1. Proximate composition of guava cheese (GC).

\begin{tabular}{|c|c|c|c|c|c|c|}
\hline Treatments & $\begin{array}{l}\text { Moisture } \\
\text { (\%) }\end{array}$ & $\begin{array}{l}\text { Ash } \\
(\%)\end{array}$ & $\begin{array}{l}\text { Protein } \\
\text { (\%) }\end{array}$ & $\begin{array}{l}\text { Fat } \\
(\%)\end{array}$ & $\begin{array}{c}\text { Carbohydrates } \\
\text { (\%) }\end{array}$ & $\begin{array}{c}\text { Total Sugars } \\
(\%)\end{array}$ \\
\hline $0 \%(\mathrm{P})$ & $66.99 \pm 0.49^{\mathrm{a}}$ & $0.77 \pm 0.03^{\mathrm{b}}$ & $2.38 \pm 0.06^{\mathrm{b}}$ & $0.58 \pm 0.05^{\mathrm{a}}$ & $29.28 \pm 0.51^{\mathrm{a}}$ & $41.49 \pm 0.00^{\mathrm{a}}$ \\
\hline $0.5 \%(\mathrm{P})$ & $66.23 \pm 0.21^{\mathrm{a}}$ & $1.01 \pm 0.01^{\mathrm{a}}$ & $3.53 \pm 0.10^{\mathrm{a}}$ & $0.54 \pm 0.06^{\mathrm{a}}$ & $28.69 \pm 0.14^{\mathrm{a}}$ & $38.07 \pm 0.00^{\mathrm{a}}$ \\
\hline $1 \%(\mathrm{P})$ & $67.67 \pm 1.32^{\mathrm{a}}$ & $0.98 \pm 0.02^{\mathrm{a}}$ & $3.23 \pm 0.11^{\mathrm{a}}$ & $0.56 \pm 0.03^{\mathrm{a}}$ & $27.56 \pm 1.23^{\mathrm{a}}$ & $40.14 \pm 0.00^{\mathrm{a}}$ \\
\hline $1.5 \%(\mathrm{P})$ & $67.39 \pm 1.92^{\mathrm{a}}$ & $0.97 \pm 0.01^{\mathrm{a}}$ & $3.17 \pm 0.31^{\mathrm{ab}}$ & $0.56 \pm 0.02^{\mathrm{a}}$ & $27.91 \pm 5.7^{\mathrm{a}}$ & $40.27 \pm 0.00^{\mathrm{a}}$ \\
\hline
\end{tabular}

Values $(n=3)$ are means \pm SEM; Means in a column with superscripts without a common letter differ $p \leq 0.05(n=3)$. 


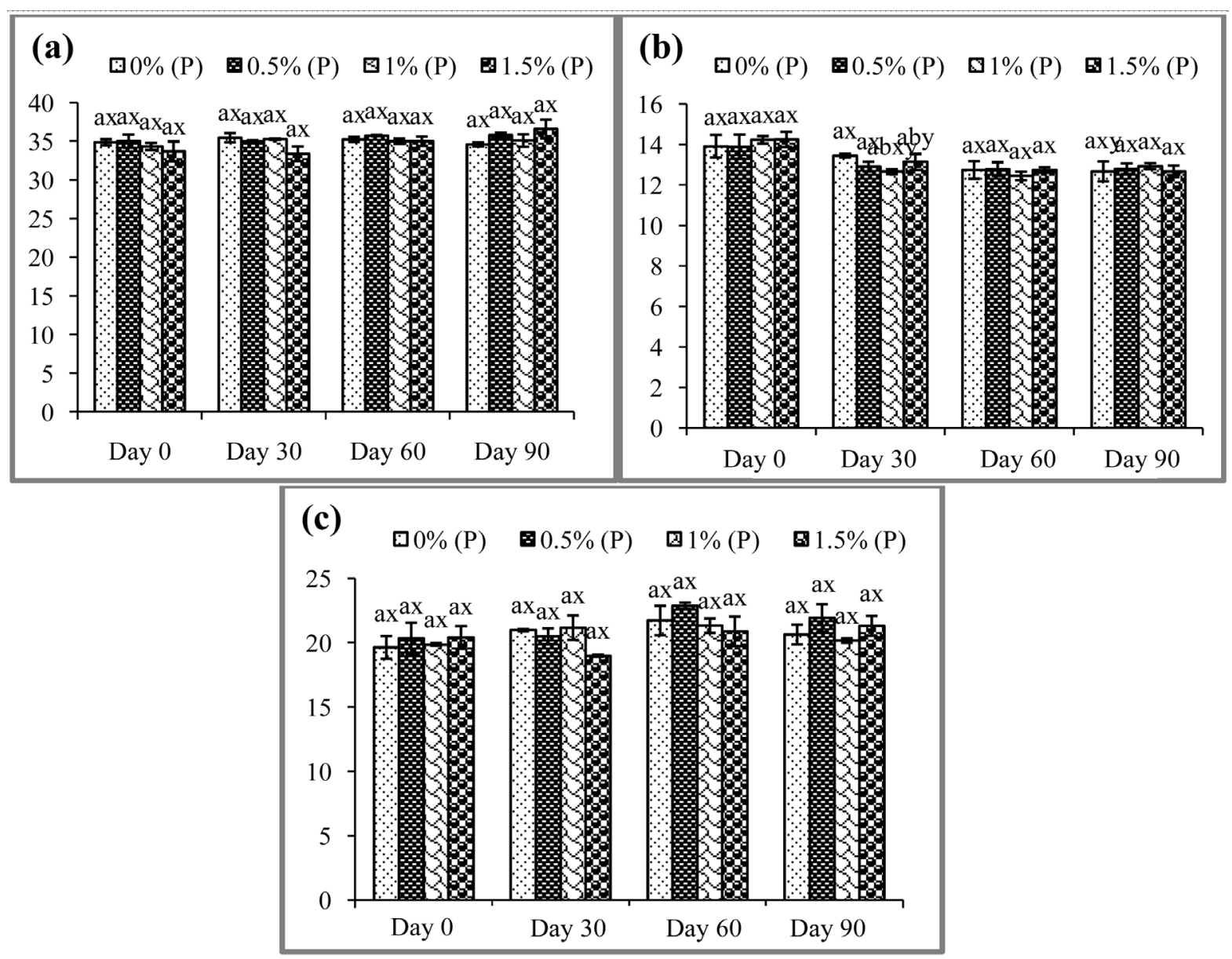

Figure 1. L* (a) (darkness to lightness), a* (b) (greenness to redness), and b* (c) (yellowness to blueness) values of guava cheese $[0 \%, 0.5 \%(\mathrm{P}), 1 \%(\mathrm{P})$, and $1.5 \%(\mathrm{P})]$ over 90 days of storage Bars $(\mathrm{n}=3)$ expressed as means \pm SEM. Means on bars with superscripts $\left({ }^{\mathrm{ab}}\right)$ without a common letter differ $\mathrm{p} \leq 0.05$. Means within the guava cheese on different days with superscript $\left({ }^{\mathrm{xy}}\right)$ without a common letter differ significantly at $\mathrm{p} \leq 0.05$. Abbreviation: (P)-pectin.

varied from $25 \%$ to $82 \%$ (0 - $10.08 \mathrm{mg})$. DPPH radical scavenging activity increased with an increase in the concentration of GC (Figure 4). Radical scavenging ability of 0\% (P), 0.5\% (P), 1\% (P) and 1.5\% (P) leveled off after inhibition of the DPPH radical by $82 \%$. Inhibition concentration $\left(\mathrm{IC}_{50}\right)$ of $0 \%(\mathrm{P}), 0.5 \%(\mathrm{P}), 1 \%(\mathrm{P})$ and $1.5 \%(\mathrm{P})$ was similar and observed at $0.008 \mathrm{mg}$.

\subsection{Sensory Evaluation}

Attributes used for sensory evaluation of the guava cheese (GC) were: handfeel, firmness, springiness mouth feel flavor and overall acceptability. The preferences for all treatments by panelists regarding sensory attributes were ranked on a 5-point hedonic scale (Figure 5). The rating for firmness, mouthfeel, flavor and overall acceptability of $0 \%(\mathrm{P})$ and $1 \%(\mathrm{P})$ GC were similar. Whereas, 1.5\% (P)GC and $0.5 \%(\mathrm{P}) \mathrm{GC}$ were scored lower by panelists for sensory parameters such as firmness, mouthfeel, flavor and overall acceptability.

\section{Discussion}

The global market of functional foods targeting physical and mental well-being has caused the food industry to increase research and development of these foods [28]. The demand of value-added fruit based products with antioxidant activity has been on the rise. Since shelf life of the fruits is relatively short, multiple methods have been applied to increase the shelf life of fruits, and one of the common methods is a fruit based product [29] [30]. Guava Cheese (GC) is semi-solid concentrated fruit slice that is widely consumed as a snack in many part of the 


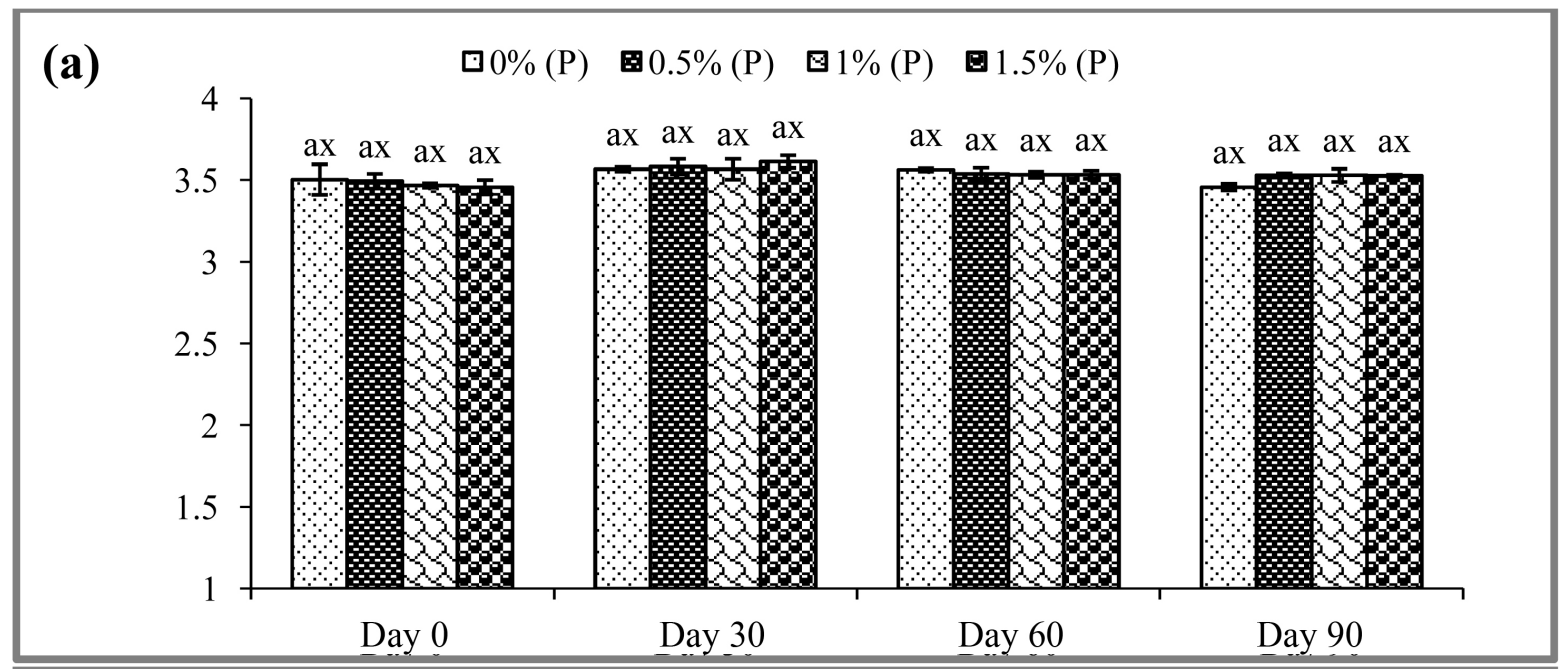

(b) $\square 0 \%(\mathrm{P}) \quad \mathbf{0} 0.5 \%(\mathrm{P}) \quad \square 1 \%(\mathrm{P}) \quad \square 1.5 \%(\mathrm{P})$

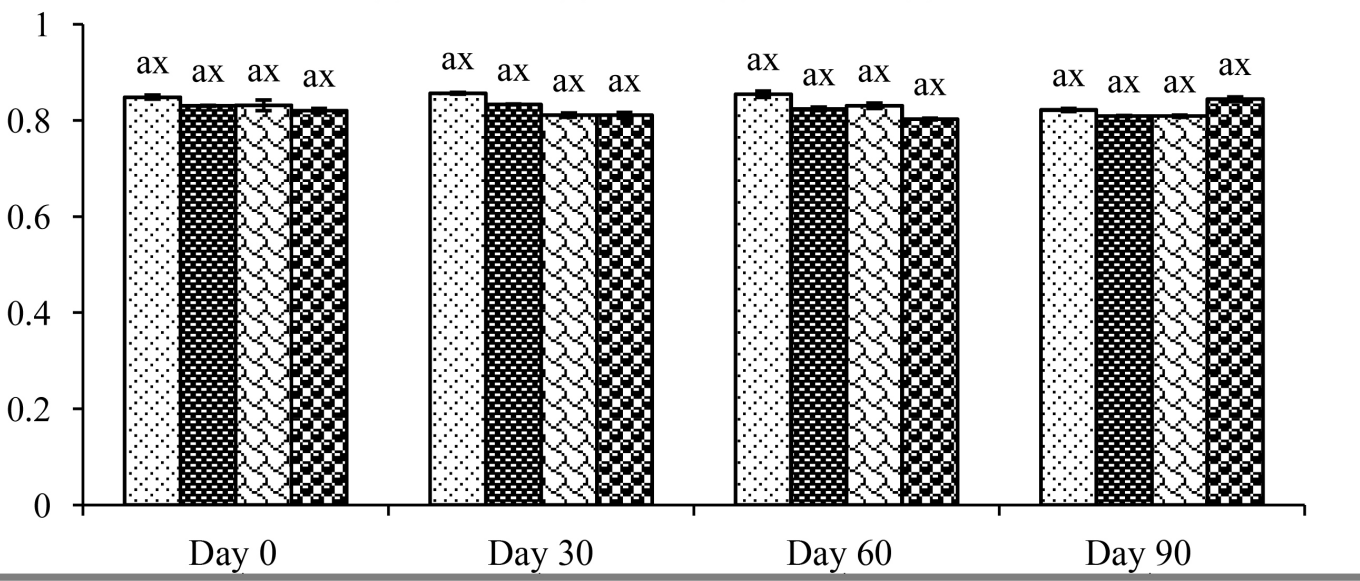

Figure 2. $\mathrm{pH}(\mathrm{a})$ and water activity (b) of guava cheese $[0 \%, 0.5 \%(\mathrm{P}), 1 \%(\mathrm{P})$, and $1.5 \%(\mathrm{P})]$ over 90 days of storage. Bars $(\mathrm{n}=3)$ expressed as means \pm SEM. Means on bars with superscripts $\left({ }^{\mathrm{ab}}\right)$ without a common letter differ $\mathrm{p} \leq 0.05$. Means within the guava cheese on different days with superscript $\left({ }^{\mathrm{xy}}\right)$ without a common letter differ significantly at $\mathrm{p} \leq 0.05$. Abbreviation: $(\mathrm{P})$-pectin.

world, produced by dehydration of fruit pulp. Guava is a highly perishable fruit but also an excellent source of antioxidants. Psidium guajava (guava) is a rich source of vitamin C and has high antioxidative properties, which is closely related to the phenolic content that is present in the fruit. Hydrocolloids have been used as gelling or thickening agents to improve texture profile for fruit leathers. Hydrocolloids have a higher water binding capacity, which can be utilized to enhance the texture profile of food products. Color, water activity, and $\mathrm{pH}$ values of $0 \%(\mathrm{P}), 0.5 \%(\mathrm{P}), 1 \%(\mathrm{P})$ and $1.5 \%(\mathrm{P})$ were consistent throughout the 90-day storage period. Physical properties of GC remained unchanged over the 90-day storage period, which might be due to the aluminum foil wrap and vacuum packaging. A study on guava leather and its storage stability in four different packing materials from which metalized polyester polyethylene and aluminum foil showed minimum loss of moisture content and water activity under ambient and low-temperature conditions [31]. A recent study on the effect of apple juice concentration (AJC), blackcurrant juice concentration (BJC) and pectin levels on fruit leather revealed that with increase in concentration of pectin $(0 \%, 2 \%, 4 \%)$ increased moisture content, Chroma and hardness of apple and blackcurrant fruit leathers. This difference may be due to the type of fruit, or the level of pectin used [32]. A study on the effect of hydrocolloids (pectin 1\% and 3\%) on mango leather found no changes in moisture content after drying for 2 hours but positively affected the color and texture parameters of mango leather compared to control [33]. The addition of pectin to the GC was effective in stabilizing the physical parameters over the 90-day storage period. 

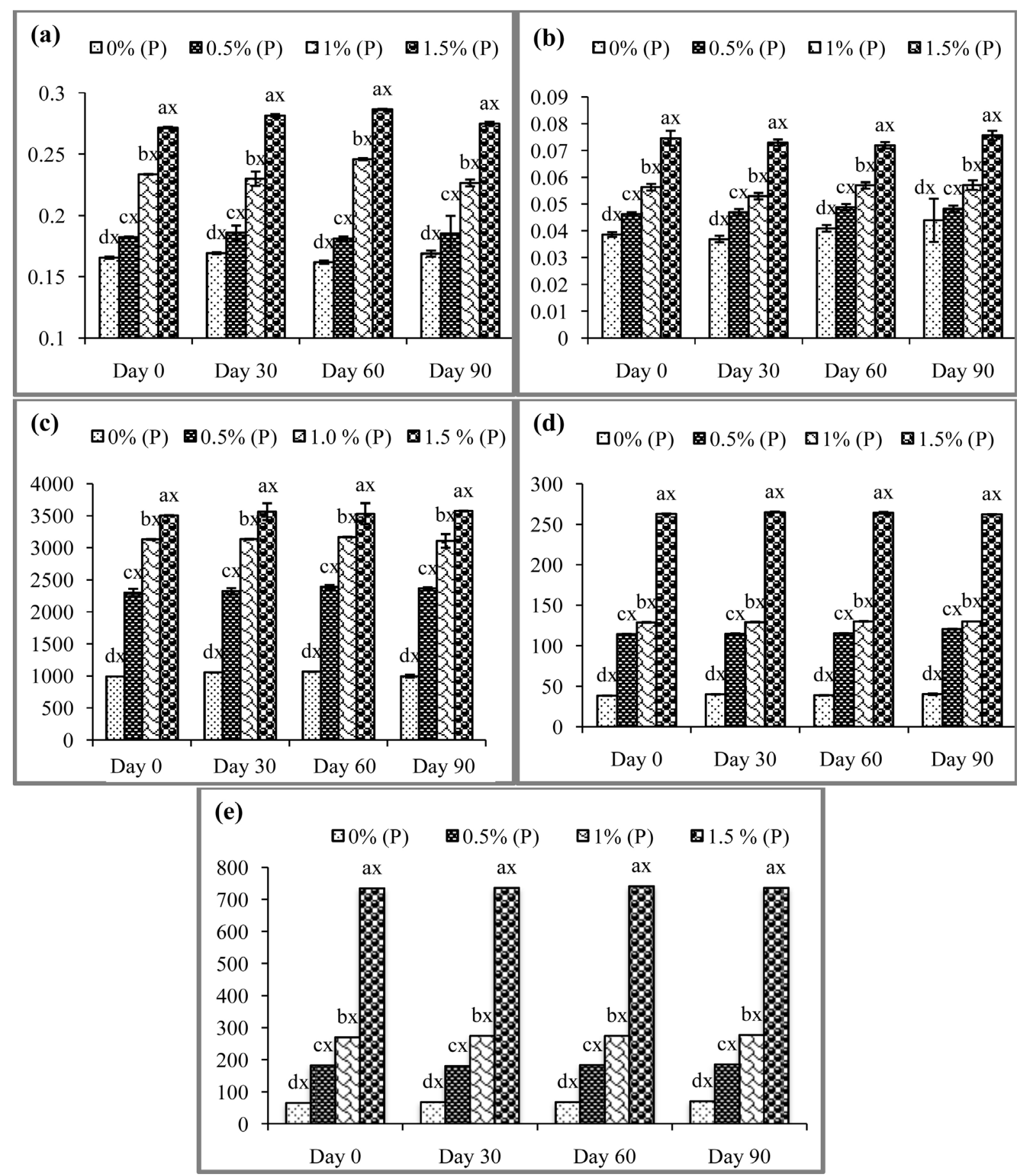

Figure 3. Changes in springiness (a), cohesiveness (b), hardness (c), gumminess (d), and chewiness (e) of guava cheese [0\% $(\mathrm{P}), 0.5 \%(\mathrm{P}), 1 \%(\mathrm{P})$, and $1.5 \%(\mathrm{P})$ ] over 90 days of storage Bars $(\mathrm{n}=3)$ expressed as means \pm SEM. Means on bars with superscripts $\left({ }^{\mathrm{ab}}\right)$ without a common letter differ $\mathrm{p} \leq 0.05$. Means within the guava cheese on different days with superscript $\left({ }^{\mathrm{xy}}\right)$ without a common letter differ significantly at $\mathrm{p} \leq 0.05$. Abbreviation: (P)-pectin.

Along with flavor, texture and appearance are the main factors for consumer acceptability of food products [34]. Texture profile analysis (TPA) was conducted on GC [0\% (P), 0.5\% (P), $1 \%(\mathrm{P}), 1.5 \%(\mathrm{P})]$ on the primary (hardness, springiness) and secondary parameters (cohesiveness, gumminess, chewiness). Pectin was found to be the most influencing factor that affected TPA values. Increased concentration of pectin significantly $(\mathrm{p} \leq$ 
Table 2. Total phenolic content and flavonoid content by SPE method.

\begin{tabular}{ccc}
\hline & Total Polyphenols (mg GAE/100g) & Total Flavonoids (mg CE/100g) \\
\hline $0 \%(\mathrm{P})$ & $201.94 \pm 0.09^{\mathrm{c}}$ & $86.63 \pm 5.53^{\mathrm{b}}$ \\
$0.5 \%(\mathrm{P})$ & $340.25 \pm 0.04^{\mathrm{b}}$ & $90.72 \pm 16.60^{\mathrm{b}}$ \\
$1 \%(\mathrm{P})$ & $506.22 \pm 0.01^{\mathrm{ab}}$ & $117.06 \pm 25.35^{\mathrm{ab}}$ \\
$1.5 \%(\mathrm{P})$ & $583.68 \pm 0.04^{\mathrm{a}}$ & $123.21 \pm 30.80^{\mathrm{a}}$ \\
\hline
\end{tabular}

Values $(n=3)$ are means \pm SEM; Means in a column with superscripts without a common letter differ $\mathrm{p} \leq 0.05$. Abbreviations: GAE—gallic acid equivalents, $\mathrm{CE}$-catechin equivalents (P)-pectin.

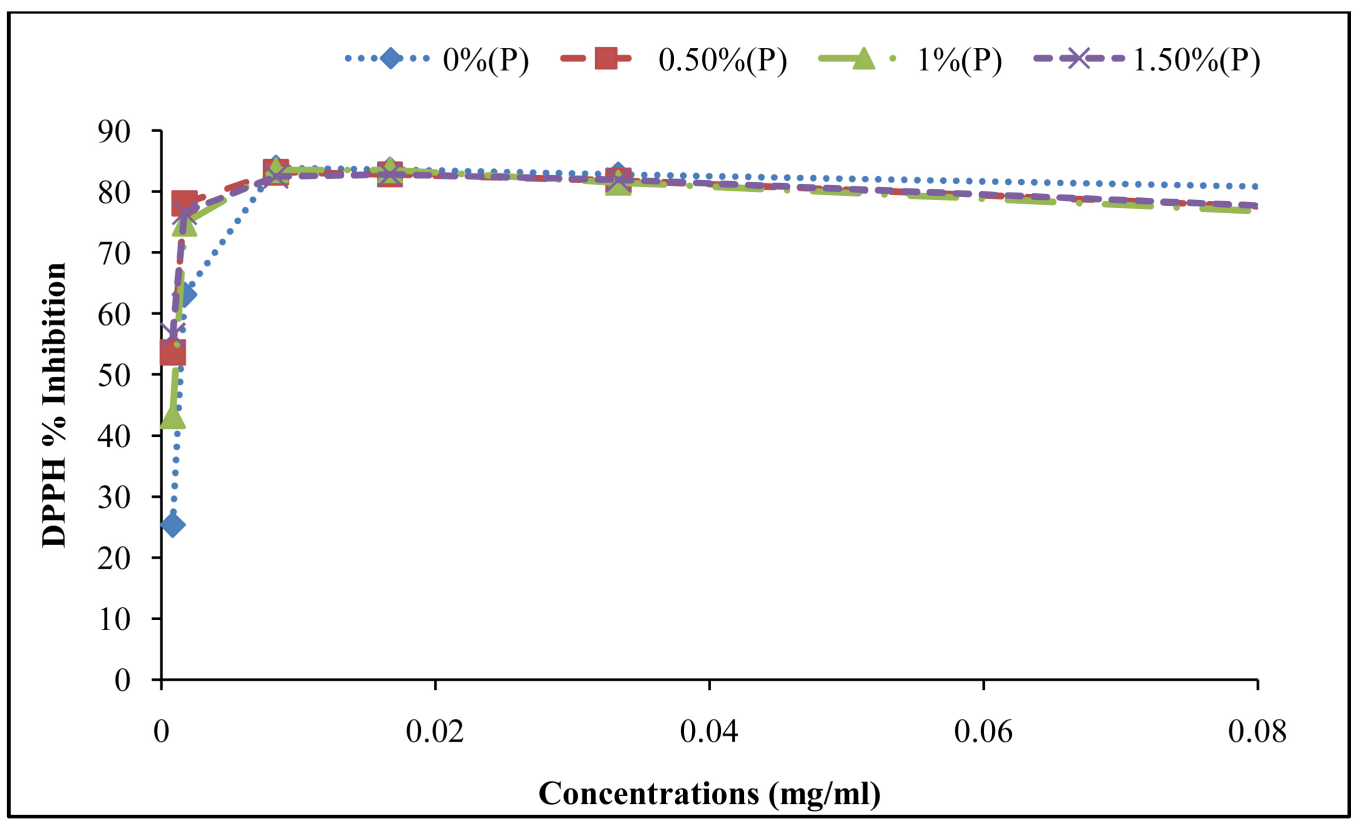

Figure 4. Percent DPPH inhibition of guava cheese $[0 \%(\mathrm{P}), 0.5 \%(\mathrm{P}), 1 \%(\mathrm{P})$, and $1.5 \%(\mathrm{P})]$ by SPE method. Values $(\mathrm{n}=3)$ are means \pm SEM. Abbreviation: DPPH-2, 2-diphenyl-1-picrylhydrazyl.

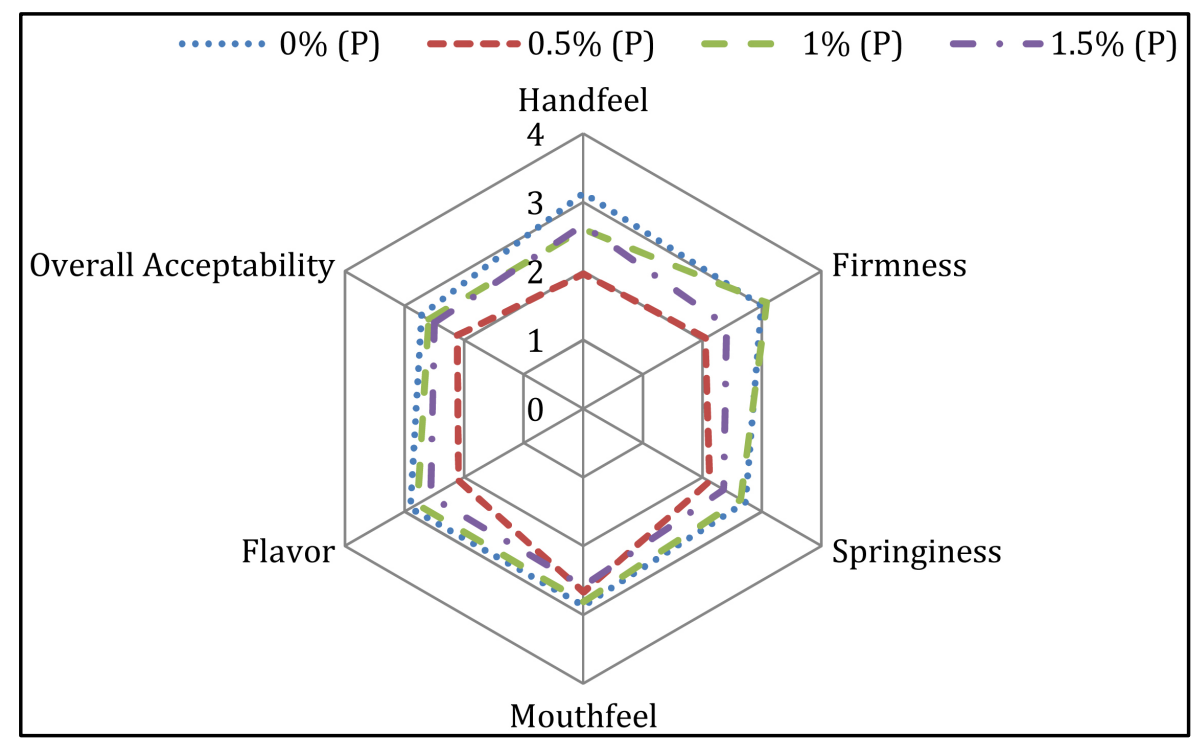

Figure 5. Sensory evaluation of guava cheese $(0 \%(P), 0.5 \%(P), 1 \%(P), 1.5 \%(P))$ on day-0. Values $(n=3)$ are means \pm SEM. Abbreviations: (P)—pectin. 
0.05) increased the hardness, springiness, cohesiveness, gumminess and chewiness of GC with no significant ( $\mathrm{p} \leq$ 0.05) effect of storage period. Pectin molecules form cross-linkages with sugar by bonding to hydrogen molecules at a low $\mathrm{pH}$, which could result in higher hardness, springiness, cohesiveness, gumminess, and chewiness of pectin added GC. A study by on the effects of pectin levels on pineapple leather with glucose syrup and pectin found that addition of glucose syrup $(2 \%, 4 \%, 6 \%)$ and pectin concentrations $(0.5 \%, 1 \%, 1.5 \%)$ did not affect the moisture and Aw of pineapple leather but increased tensile force and work [35]. To decrease the hardness, pectin content may be reduced to get a desirable product.

The untrained panelists equally liked the firmness, mouthfeel, flavor and overall acceptability of the $0 \%(\mathrm{P})$ and 1\% (P) GC. Based on these results, pectin may be utilized in combination with alternative sweeteners to achieve the desired texture.

During cheese preparation, guava was subjected to a high temperature for anextended time. To determine the effects of thermal treatment on antioxidant properties of guava cheese (GC), physiochemical quantification (total polyphenols, flavonoids) and antioxidant assays (DPPH radical scavenging activity) were conducted. Total phenolic and flavonoid contents of 1.5\% (P) GC were significantly ( $\mathrm{p} \leq 0.05$ ) higher compared to $1 \%(\mathrm{P}), 0.5 \%$ $(\mathrm{P})$, and $0 \%(\mathrm{P})$. Pectin forms a three-dimensional structure when subjected to heat [36]. Low methoxy pectin (LMP) is based upon the clustering of pectin with calcium ions, which cause the occurring of the cavities occupied by the carboxyl and hydroxyl group [37] [38]. Formation of these cavities may have the ability to hold the phytochemicals and prevent from thermal degradation. A study regarding the effect of pectin, process and storage conditions on anthocyanin and color of strawberry jams and spreads revealed that LMP has better a antioxidant stabilization property [5]. Many other researchers [37] [39]-[41] have found the positive effects of pectin on stabilization of color and antioxidant properties of gelled fruit based products (raspberry jam, bilberry jam and black current). Hence, pectin may be utilized to enhance the color and antioxidant properties of fruit based products.

\section{Conclusion}

Shelf stable guava cheese (GC) was developed to evaluate the utilization of exotic guava fruit. Pectin played a major role in the GC that was developed in this study. Addition of pectin to the GC increased the hardness and phytochemical content. Pectin enhanced the shelf life stability and antioxidant potential of guava cheese.

\section{References}

[1] Huang, X. and Hsieh, F.H. (2005) Physical Properties, Sensory Attributes, and Consumer Preference of Pear Fruit Leather. Journal of Food Science, 70, E177-E186. http://dx.doi.org/10.1111/j.1365-2621.2005.tb07133.x

[2] Khan, R.S., Grigor, J., Winger, R. and Win, A. (2013) Functional Food Product Development-Opportunities and Challenges for Food Manufacturers. Trends in Food Science \& Technology, 30, 27-37. http://dx.doi.org/10.1016/j.tifs.2012.11.004

[3] Conlon, L.E. and Erdman Jr., J.W. (2015) Nonnutritive Components in Foods and Cancer Risk. In: Bendich, A. and Deckelbaum, R.J., Eds., Preventive Nutrition, Springer International Publishing, 215-242. http://dx.doi.org/10.1007/978-3-319-22431-2 12

[4] Selani, M.M., Bianchini, A., Ratnayake, W.S., Flores, R.A., Massarioli, A.P., de Alencar, S.M. and Brazaca, S.G.C. (2016) Physicochemical, Functional and Antioxidant Properties of Tropical Fruits Co-Products. Plant Foods for Human Nutrition, 71, 1-8. http://dx.doi.org/10.1007/s11130-016-0531-z

[5] Holzwarth, M., Korhummel, S., Siekmann, T., Carle, R. and Kammerer, D.R. (2013) Influence of Different Pectins, Process and Storage Conditions on Anthocyanin and Colour Retention in Strawberry Jams and Spreads. LWT_Food Science and Technology, 52, 131-138. http://dx.doi.org/10.1016/j.lwt.2012.05.020

[6] US Department of Health and Human Services and US Department of Agriculture (2015) 2015-2020 Dietary Guidelines for Americans. 8th Edition. http://health.gov/dietaryguidelines/2015/guidelines/

[7] Gehlot, R. and Singh, R. (2007) Changes in Chemical Composition of Bael-Guava Cheese and Toffee during Storage. Haryana Journal of Horticultural Sciences, 36, 241-243. http://www.cabdirect.org/abstracts/20093253020.html

[8] Ellshoff, Z.E., Gardner, D.E., Wikler, C. and Smith, C.W. (1995) Annotated Bibliography of the Genus Psidium, with Emphasis on P. cattleianum (Strawberry Guava) and P. guajava (Common Guava), Forest Weeds in Hawai'i. http://hdl.handle.net/10125/7258

[9] Pommer, C.V. and Murakami, K.R. (2009) Breeding Guava (Psidium guajava L.) In: Breeding Plantation Tree Crops: Tropical Species, Springer, New York, 83-120. http://dx.doi.org/10.1007/978-0-387-71201-7_3 
[10] Dhiman, A., Nanda, A., Ahmad, S. and Narasimhan, B. (2011) In Vitro Antimicrobial Activity of Methanolic Leaf Extract of Psidium guajava L. Journal of Pharmacy and Bioallied Sciences, 3, 226.

http://www.jpbsonline.org/text.asp?2011/3/2/226/80776 http://dx.doi.org/10.4103/0975-7406.80776

[11] Mercadante, A.Z., Steck, A. and Pfander, H. (1999) Carotenoids from Guava (Psidium guajava L.): Isolation and Structure Elucidation. Journal of Agricultural and Food Chemistry, 47, 145-151. http://dx.doi.org/10.1021/jf980405r

[12] Miean, K.H. and Mohamed, S. (2001) Flavonoid (Myricetin, Quercetin, Kaempferol, Luteolin, and Apigenin) Content of Edible Tropical Plants. Journal of Agricultural and Food Chemistry, 49, 3106-3112. http://dx.doi.org/10.1021/jf000892m

[13] Gutiérrez, R.M.P., Mitchell, S. and Solis, R.V. (2008) Psidium guajava: A Review of Its Traditional Uses, Phytochemistry and Pharmacology. Journal of Ethnopharmacology, 117, 1-27. http://dx.doi.org/10.1016/j.jep.2008.01.025

[14] Mercado-Silva, E., Benito-Bautista, P. and de los Angeles García -Velasco, M. (1998) Fruit Development, Harvest Index and Ripening Changes of Guavas Produced in Central Mexico. Postharvest Biology and Technology, 13, 143-150. http://dx.doi.org/10.1016/S0925-5214(98)00003-9

[15] Perry, L.M. and Metzger, J. (1980) Medicinal plants of East and Southeast Asia: Attributed Properties and Uses (Vol. 620). MIT Press, Cambridge, London. http://kbd.kew.org/kbd/detailedresult.do?id=63960

[16] Kango, N. and Jain, S.C. (2011) Production and Properties of Microbial Inulinases: Recent Advances. Food Biotechnology, 25, 165-212. http://dx.doi.org/10.1080/08905436.2011.590763

[17] Kazimierczak, R., Hallmann, E., Kowalska, K. and Rembiałkowska, E. (2016) Biocompounds Content in Organic and Conventional Raspberry Fruits. Acta Fytotechnica et Zootechnica, 18, 40-42. http://dx.doi.org/10.15414/afz.2015.18.si.40-42

[18] Mayhew, A.J., de Souza, R.J., Meyre, D., Anand, S.S. and Mente, A. (2016) A Systematic Review and Meta-Analysis of Nut Consumption and Incident Risk of CVD and All-Cause Mortality. British Journal of Nutrition, 115, 212-225. http://dx.doi.org/10.1017/S0007114515004316

[19] Bonaccio, M., Di Castelnuovo, A., De Curtis, A., Costanzo, S., Bracone, F., Persichillo, M., Iacoviello, L., et al. (2015) Nut Consumption Is Inversely Associated with Both Cancer and Total Mortality in a Mediterranean Population: Prospective Results from the Moli-Sani Study. British Journal of Nutrition, 114, 804-811. http://dx.doi.org/10.1017/S0007114515002378

[20] Kasliwal, R.R., Bansal, M., Mehrotra, R., Yeptho, K.P. and Trehan, N. (2015) Effect of Pistachio Nut Consumption on Endothelial Function and Arterial Stiffness. Nutrition, 31, 678-685. http://dx.doi.org/10.1016/j.nut.2014.10.019

[21] Valdivia-López, M.Á. and Tecante, A. (2015) Chapter Two-Chia (Salvia hispanica): A Review of Native Mexican Seed and Its Nutritional and Functional Properties. Advances in Food and Nutrition Research, 75, 53-75. http://dx.doi.org/10.1016/bs.afnr.2015.06.002

[22] AACC International (1999) AACC Method 44-40.01: Moisture Modified Vaccum-Oven Method. Approved Methods of Analysis.

[23] Hunter, R.S. and Harold, R.W. (1987) The Measurement of Appearance. John Wiley \& Sons, Hoboken. http://www.gbv.de/dms/ilmenau/toc/016772857.PDF

[24] Nunes, J.C., Lago, M.G., Castelo-Branco, V.N., Oliveira, F.R., Torres, A.G., Perrone, D. and Monteiro, M. (2016) Effect of Drying Method on Volatile Compounds, Phenolic Profile and Antioxidant Capacity of Guava Powders. Food Chemistry, 197, 881-890. http://dx.doi.org/10.1016/j.foodchem.2015.11.050

[25] Singleton, V.L., Orthofer, R. and Lamuela-Raventos, R.M. (1999) Analysis of Total Phenols and Other Oxidation Substrates and Antioxidants by Means of Folin-Ciocalteu Reagent. Methods in Enzymology, 299, 152-178. http://dx.doi.org/10.1016/S0076-6879(99)99017-1

[26] Marinova, D., Ribarova, F. and Atanassova, M. (2005) Total Phenolics and Total Flavonoids in Bulgarian Fruits and Vegetables. Journal of the University of Chemical Technology and Metallurgy, 40, 255-260. https://www.researchgate.net/profile/Maria_Atanassova/publication/258769164_Total_phenolics_and_flavonoids_in_ Bulgarian_fruits_and_vegetables/links/00463528f0a28e54a6000000.pdf

[27] Brand-Williams, W., Cuvelier, M.E. and Berset, C.L.W.T. (1995) Use of a Free Radical Method to Evaluate Antioxidant Activity. LWT-Food Science and Technology, 28, 25-30. http://dx.doi.org/10.1016/S0023-6438(95)80008-5

[28] Vicentini, A., Liberatore, L. and Mastrocola, D. (2016) Functional Foods: Trends and Development of the Global Market. Italian Journal of Food Science, 28, 338-351.

[29] Patras, A., Brunton, N.P., Da Pieve, S. and Butler, F. (2009) Impact of High Pressure Processing on Total Antioxidant Activity, Phenolic, Ascorbic Acid, Anthocyanin Content and Colour of Strawberry and Blackberry Purées. Innovative Food Science \& Emerging Technologies, 10, 308-313. http://dx.doi.org/10.1016/j.ifset.2008.12.004 
[30] Sousa, M.B., Canet, W., Alvarez, M.D. and Fernández, C. (2007) Effect of Processing on the Texture and Sensory Attributes of Raspberry (cv. Heritage) and Blackberry (cv. Thornfree) Journal of Food Engineering, 78, 9-21. http://dx.doi.org/10.1016/j.jfoodeng.2005.08.047

[31] Kumar, R., Mandal, G. and Jain, R.K. (2005) Storage Stability of Guava Leather in Different Packing Materials. International Guava Symposium, Lucknow, 5-8 December 2005, 621-625.

[32] Diamante, L.M., Li, S., Xu, Q. and Busch, J. (2013) Effects of Apple Juice Concentrate, Blackcurrant Concentrate and Pectin Levels on Selected Qualities of Apple-Blackcurrant Fruit Leather. Foods, 2, 430-443. http://dx.doi.org/10.3390/foods2030430

[33] Singh Gujral, H. and Singh Brar, S. (2003) Effect of Hydrocolloids on the Dehydration Kinetics, Color, and Texture of Mango Leather. International Journal of Food Properties, 6, 269-279. http://dx.doi.org/10.1081/JFP-120017846

[34] Bourne, M. (2004) Relation between Texture and Mastication. Journal of Texture Studies, 35, 125-143. http://dx.doi.org/10.1111/j.1745-4603.2004.tb00829.x

[35] Phimpharian, C., Jangchud, A., Jangchud, K., Therdthai, N., Prinyawiwatkul, W. and No, H.K. (2011) Physicochemical Characteristics and Sensory Optimisation of Pineapple Leather Snack as Affected by Glucose Syrup and Pectin Concentrations. International Journal of Food Science \& Technology, 46, 972-981. http://dx.doi.org/10.1111/j.1365-2621.2011.02579.x

[36] Kopjar, M., Pilizota, V., Tiban, N.N., Subaric, D., Babic, J., Ackar, D. and Sajdl, M. (2009) Strawberry Jams: Influence of Different Pectins on Colour and Textural Properties. Czech Journal of Food Sciences, 27, 20-28. http://agriculturejournals.cz/publicFiles/06081.pdf

[37] Kasapis, S. (2002) Viscoelasticity of Oxidized Starch/Low Methoxy Pectin Mixtures in the Presence of Glucose Syrup. International Journal of Food Science \& Technology, 37, 403-413. http://dx.doi.org/10.1046/j.1365-2621.2002.00579.x

[38] Walkinshaw, M.D. and Arnott, S. (1981) Conformations and Interactions of Pectins: II. Models for Junction Zones in Pectinic Acid and Calcium Pectate Gels. Journal Molecular Biology, 153, 1075-1085. http://dx.doi.org/10.1016/0022-2836(81)90468-X

[39] Buchweitz, M., Speth, M., Kammerer, D.R. and Carle, R. (2013) Impact of Pectin Type on the Storage Stability of Black Currant (Ribes nigrum L.) Anthocyanins in Pectic Model Solutions. Food Chemistry, 139, 1168-1178. http://dx.doi.org/10.1016/j.foodchem.2013.02.005

[40] Lewis, C.E., Walker, J.R. and Lancaster, J.E. (1995) Effect of Polysaccharides on the Colour of Anthocyanins. Food Chemistry, 54, 315-319. http://dx.doi.org/10.1016/0308-8146(95)00026-F

[41] Poiana, M.A., Alexa, E. and Mateescu, C. (2012) Tracking Antioxidant Properties and Color Changes in Low-Sugar Bilberry Jam as Effect of Processing, Storage and Pectin Concentration. Chemistry Central Journal, 6, 4. http://journal.chemistrycentral.com/content/6/1/4 http://dx.doi.org/10.1186/1752-153X-6-4

\section{Submit or recommend next manuscript to SCIRP and we will provide best service for you:}

Accepting pre-submission inquiries through Email, Facebook, LinkedIn, Twitter, etc.

A wide selection of journals (inclusive of 9 subjects, more than 200 journals)

Providing 24-hour high-quality service

User-friendly online submission system

Fair and swift peer-review system

Efficient typesetting and proofreading procedure

Display of the result of downloads and visits, as well as the number of cited articles

Maximum dissemination of your research work

Submit your manuscript at: http://papersubmission.scirp.org/ 